\title{
Konstruksi Jurnalistik Investigasi Dalam Perspektif Analisis Wacana Model Teun A.Van Dijk (Sebuah Studi Kasus Penembakan Laskar Front Pembela Islam Di Majalah Tempo)
}

\author{
Arvin Hardian ${ }^{1}$, Tuty Mutiah ${ }^{2}$, Wulan Apriani ${ }^{3}$, Agung Raharjo ${ }^{4}$ \\ ${ }^{1}$ Universitas Bina Sarana Informatika \\ e-mail: Arvin.ahr@bsi.ac.id \\ ${ }^{2}$ Universitas Bina Sarana Informatika \\ e-mail: tuty.ttt@bsi.ac.id \\ ${ }^{3}$ Universitas Sahid Jakarta \\ e-mail: wulan1504@gmail.com \\ ${ }^{4}$ Universitas Bina Sarana Informatika \\ e-mail: agung.ajq@bsi.ac.id
}

\begin{abstract}
Cara Sitasi: Arvin H, Tuty M, Wulan A, Agung R (2021) Konstruksi Jurnalistik Investigasi Dalam Perspektif Analisis Wacana Model Teun A.Van Dijk (Sebuah Studi Kasus Penembakan Laskar Front Pembela Islam Di Majalah Tempo, 2021 21(1), 51- 59 Retrieved from https://doi.org/10.31294/jc.v19i2
\end{abstract}

\begin{abstract}
Investigation journalistic construction in the perspective of discourse analysis by Teun A. Van Dijk (A Case Study of the Islamic Defenders Front Laskar Shooting in Tempo Magazine) Van Dijk's analyst is how journalists hear and understand events. How these events are understood, through a process of meaning and mental help to understand this phenomenon as part of the news production process, which refers to the code of ethics and legal norms that apply. Meanwhile, Investigation journalism must have at least some basic elements of investigation. As; uncovering crime, wide-scale, answering all important public questions, placing the actors involved in a straightforward manner, and the public can understand the complexity of the problem. Results of the analysis; The Tempo reporter in the above case wanted to convey that the public has a position before the law. Tempo Magazine also wants to show its accuracy in compiling a cover both side chronology of the shooting of FPI members as well as protecting sources who are not willing to be identified. Furthermore, in a sematical manner, the Tempo journalist questioned Rizieq's incitement article. In the end of his report, the Tempo reporter wanted to invite his readers to describe the situation in Megamendung after Rizieq's return from Saudi Arabia by giving a strong impression of security in the hope that the public impression would be authentic.
\end{abstract}

Keywords: Investigation, journalistic production.

\section{PENDAHULUAN}

Sudah lama jurnalisme hanya bergerak di permukaan, mempublikasikan pernyataan-pernyataan normatif, dan mempopulerkan selebritas yang pandai menarik perhatian khalayak dengan penampilan di luar kewajaran. Sudah tepat jika jurnalisme di era new media kembali memberi perhatian lebih pada investigasi jurnalistik. Perkembangan new media justru dinilai memiliki banyak manfaat bagi kegiatan jurnalistik investigasi.

Adalah tugas jurnalisme, lebih khusus jurnalisme investigatif, demokratisasi informasi. Keberadaan ekosistem data terbuka ini jelas memudahkan jurnalis mencari informasi awal dan memverifikasi dugaan-dugaan penyimpangan. Teknologi digital juga memungkinkan analisis data yang lebih tajam, serta visualisasi data yang lebih kaya dan menarik.
Idealnya sebuah karya jurnalistik yang diproduksi oleh media massa dapat yang diapresiasi publik demi memenuhi rasa naluri ingin tahu pembacanya. Tentunya dengan menyeimbangkan antara idealisme dan komersialisme industri media itu sendiri. Sebuah karya itu betul-betul mampu memberikan pencerahan kepada publik pembaca. Sebuah keniscayaan, ketika sebuah karya justru menimbulkan kegaduhan dan mengahakimi pribadi orang lain atas tindak pindana yang belum mendapat kepastian hukum (trial by the press), dapat kecaman oleh pihak yang merasa dirugikan. Meskipun demikian tentu saja masih ada ruang argumentasi buat karya jurnalistik investigasi yang notabene masih dianggap kontroversial.

\section{METODOLOGI PENELITIAN}

Mencermati Jurnalisme Investigasi Majalah Tempo (Analisis Wacana Jurnalisme Investigasi Polisi 
Versus FPI Majalah TEMPO edisi (13/12/2020.) Dalam hal ini penulis melakukan pendekatan deskriptif kualitatif yang fokus pada analisa berita dengan menggunakan tehnik analisis wacana model Teun A.Van Dijk.

Adapun metode pengumpulan data yang dilakukan adalah riset kepustakaan, pengamatan, dokumentasi ,dan penelusuran secara online. Fokus penelitian berusaha membahas bagaimana tragedi meninggalnya enam orang anggota FPI yang diduga melawan petugas saat mengawal Habib Rizieq di km 50 Jalan Tol Cikampek . Deskripsi fokus adalah, bagaimana reportase investigasi majalah Tempo "mengendus adanya" jejak-jejak kaki" peristiwa tertentu dari tempat kejadian perkara. Dalam kegiatan pers, hal itu bisa mengkonotasikan berbagai bukti yang dapat dijadikan fakta, yang sengaja dicari dan diselidiki.

Permasalah pokok yang diajukan Van Dijk adalah, bagaimana wartawan mendengar, dan memahami peristiwa. Bagaimana peristiwa tersebut dimengerti, dimaknai dan ditampilkan dalam pikiran. Adalah analisis kognisi sosial memusatkan perhatian pada struktur mental, karena melalui proses pemaknaan dan mental wartawan membantu memahami fenomena tersebut sebagai bagian dari proses produksi berita.

Dalam hal ini penulis menggunakan analisis wacana Teun Van Dijk. Agar dapat mencermati dan memahami sedikitnya harus memiliki enam komponen tematik (struktur makro) Van Dijk mendefenisikan topik sebagai struktur makro dari teks. Skematik (Super struktur) Skematik merupakan strategi dari komunikator untuk mendukung makna umum dengan memberikan sejumlah alasan pendukung. Semantik (Mikro Struktur) Semantik dalam skema Van Dijk dikategorisasikan sebagai makna lokal yakni makna yang muncul dari hubungan antar kalimat yang membangun makna tertentu dalam suatu hubungan teks. Sintaksis (Mikro struktur) Merupakan politik bahasa lewat bahasa seperti pada pemaknaan kata ganti, kalimat aktif, dan kalimat pasif. Secara epistimologis, sintaksis berarti menempatkan bersama-sama kata-kata menjadi kelompok kata atau kalimat. Stilistik (Mikro struktur) Pusat perhatian kajian ini adalah pada gaya (style) yaitu cara yang digunakan oleh seorang pembicara atau penulis untuk menyatakan maksudnya dengan menggunakan bahasa sebagai mediumnya khususnya teks dalam ragam tulis. Retoris (Struktur mikro) Retoris mempunyai fungsi dalam penekanan dalam teks yang berhubungan erat pada bagaimana pesan itu disampaikan kepada khalayak. yang dimaksudkan sebagai ornamen atau bumbu dari suatu teks.
Lewat pandangan analisis wacana Teun A.Van Dijk penulis berusaha membedah analisa wacana dengan memaknai satuan bahasa di atas kalimat di Majalah TEMPO edisi 13/12/2020. Lazimnya, perluasan arti istilah inilah yang dikaitkan dengan konteks yang lebih luas yamg mempengaruhi makna rangkaian ungkapan secara keseluruhan. Dalam hal ini penulis juga mempertimbangkan konteks yang lebih luas lagi untuk memahami bagaimana konteks itu mempengaruhi kalimat

\section{HASIL DAN PEMBAHASAN}

Berawal Rest Area Km 50 Jalan Tol JakartaCikampek, Senin dinihari, 7 Desember lalu. Hampir semua media tertuju pada kasus kematian laskan FPI yang mengawal Habib Rizieq .Strategi wacana jurnalisme investigasi pada majalah tempo edisi Polisi VS FPI memiliki peran yang sangat signifikan dalam menginformasikan kasus-kasus investigasi. Apalagi menyangkut kepentingan publik.

Kali ini masalah meninggalnya laskar FPI tidak luput laporan investigasi majalah Tempo yang mendalam. Salah satu kasus yang mungkin tidak banyak orang tahu adalah: Mengapa peristiwa ini terjadi. Bagaimana kronologi peristiwa sehingga apparat Kepolisan mengambil tindakan yang konon dianggap melangar HAM? Siapa, bahkan apa yang dia perbuat sehingga enam anggta laskas FPI harus meregang nyawa.

Tidak dapat dipungkir naluri wartawan Tempo melakukan penelusuran jurnalisme investigasi dalam mengungkap cerita sang enam orang lascar FPI sebagai suatu pelanggaran hak asasi manusiadi penghujung akhir 2020 .

Habib Rizieq Shihab adalah pemimpin kultural yang memiliki pengaruh luar biasa diamta masyarkat. Namun catatan sejarah Indonesia kasus meninggalnya enam laskar FPI bukan satu-satunya korban pelanggaran HAM berat. Dalam catatan redaksi Tempo disebutkan sepanjang sejarah Orde Baru, kasus serupa bukan hal yang baru. Tapi cerita kematian enam laskan FPI menjadi catatan penting dalam sejarah pemerintahan presiden Jokowie yang tak layak diabaikan. Sepulang dari Saudi Arabia, Habib Rizieq lewat "Revolusi Ahlaq" dinilai dapat merongrong wibawa pemerintah, meskipun saat ini harus mendekam di Polda Metro Jaya dengan tuduhan pasal penghasutan yang hingga kini hingga kini menjadi keraguan public

Dari sisni Van Dijk juga melihat bagaimana struktur sosial, dominasi, dan kelompok kekuasaan yang ada dalam masyarakat dan bagaimana kognisi/pikiran serta kesadaran anggota yang membentuk dan berpengaruh terhadap teks- teks tertentu. Analisisnya juga menghubungkan analisis tekstual majalah 
Tempo ke arah analisis yang komprehensif, bagaimana teks diproduksi, baik dalam hubungannya dengan indivudu, wartawan dan masyarakat

Sebuah teks tak pernah lepas dari ideologi dan memiliki kemampuan untuk memanipulasi ke arah suatu ideologi. Ideologi sebagai konsep sentral dalam analisis wacana yang bersifat kritis. Hal ini, menurutnya karena teks, percakapan dan lainnya adalah bentuk dari praktik ideologi atau pencerminan dari ideologi tertentu.

\section{A. Hasil Analisis Judul Editorial: "Penembakan oleh Polisi di era Orde Baru" pada Struktur wacana Van Dijk}

Seperti kita ketahui teks editorial yang berisi pendapat dan sudut pandang redaksi terhadap masalah yang dibicarakan pada saat surat kabar itu diterbitkan. Adapun teks editorial bertujuan untuk mengajak pembaca untuk ikut berpikir tentang masalah yang sedang dibicarakan sekaligus memberikan opini atau pandangan redaksi kepada pembaca.

1. Editorial Tempo berusaha mengingatkan memori pembaca bahwa penembakan oleh aparat juga terjadi di era Orde Baru . Teks editorial terkadang mampu menggerakkan pembaca untuk mengiatkan kembali memori pembaca terhadap kasus sejenis untuk menumbuhkan pemikiran pembaca. Dalam editorial secara jelas mengajak pembaca menuju latar masalah yang menjelaskan tentang sesuatu yang akan dibahas atau dibaca, khususnya era Orde Baru, banyak kasus polisi yang menembak warga sipil. Majalah Tempo edisi 5 September 1981 berjudul "Korbankorban Petugas Ngoboi"

2. Memeiliki maslah yang sama soal "human interst" pada kasus Suratmi yang meregang nyawa dengan Iuka akibat peluru yang menembus ubun-ubun sampai bagian bawah telinganya. Kondisi jenasah dengan tangan dan kakinya terikat sobekan kain. Suratmi tewas di tangan Sibero setelah bocah itu bersama teman-temannya mengumpulkan buah kelapa sawit yang tercecer di tanah. Latar ini menghantarkan pembaca ke zaman Orde Baru dimana banyak kasus, aparat yang menembak warga sipil. Seperti kasius Suratmi, gadis kecil 11 tahun, salah satunya. Ia ditembak Kapten lnfanteri S. Sibero ketika mengambil kelapa sawit di perkebunan Mayang, PTP VII Sumatera Utara.

3. Judul Editorial: Penembakan oleh Polisi di era Orde Baru pada struktur makro wacana Van Dijk, sedikitnya terdapat tiga tema besar 1)Penembakan anggota FPI oleh polisi menuai kontradiksi . 2)Baik polisi maupun FPI memiliki versi masing-masing mengenai kronologi penembakan itu. 3) Di zaman Orde Baru, banyak kasus polisi yang menembak warga sipil.

4. Dalam super struktur dan skema penulisaanya editor Tempo menyampaikan informasi soal kontradiksi polisi dan FPI soal perbedaan prespektif tentang kronologi penembakan. Polda Metro Jaya, menyatakan polisi menembak mati enam anggota Front Pembela Islam pada 7 Desember 2020 di kilometer 50 jalan tol Cikampek dalam upaya membela diri dari serangan senjata api dan senjata tajam. Sementara itu, versi Sekretaris Umum FPI Munarman, enam anggota laskar tersebut diculik sebelum polisi mengeksekusinya

5. Dalam wacana versi Van Dijk dalam editorialnya Tempo menyoal struktur mikro dengan tema, "pertentanngan" pernyataan dari dua kubu yang sedang bertikai.

6. Strategi jurnalisme investigasi dalam editorial Tempo, mengingatkan masyarakat pembaca dengan mengkomperasi sebuah fakta hasil investigasi saat Orde Baru berkuasa, dimana aparat keamanan seolah-olah "dihalalkan" menembak orang yang masih "patut diduga" melakukan tidakan yang dianggap kriminal. Bahkan kejadian di Sumetera Utara menimpa anak dibawah umur yang harus meregang nyawa karena dicurigai mencuri buah sawit.

7. Dalam koherensi (konjungsi kata) terdapat kata "penembakan " terkait kasus kematian enam laskar FPI ada keselarasan hubungan kasus Suratmi . Editorial majalah Tempo mencoba mengingatkan kepada pembaca dengan menggambarkan betapa ganasnya oknum aparat bersenjata ketikla memindak pelaku pencurian anak dibawah umur dan kasus sejenis di jaman orde baru.

8. Pesan ini dibuka dalam editorial Tempo edisi "Polisi Versus FPI" merupakan gambaran, betapa buruknya tindakan Polisi dalam menangani keamanan. Bahkan enam orang anggota FPI harus berakhir di kamar mayat karena hanya melakukan pengawalan dari seorang Habib. Penembakan enam lascar FPI bisa menjadi pucak sekam yang selama ini meranggas, setelah silang pendapat berbagai kalanagan merangsek di jagat maya.

9. Sebagai media independent dan professional, narasi editorialnya redaksi Tempo tetap memperhatikan bagaimana caara pemberitaan dan menyatakan pendapat dalam editorialnya. Seperti yang termaktub dalam UU 40 tahu 1999 Pasal 5 Wartawan Indonesia menyajikan berita secara berimbang dan adil, mengutamakan kecermatan dari kecepatan serta tidak mencampur adukkan fakta dan opini sendiri. Karya jurnalistik berisi interprestasi dan opini wartawan, agar disajikan dengan menggunakan nama jelas penulisnya dalam meliput berita dan menulis berita sampai dengan mengetik berita dengan maksud untuk memperoleh gambaran interperatif 
redaksi di surat kabar. Sampai disini editor Tempo sangat memperhatikan rumusan diatas.

10. Editor Tempo dalam narasinya juga sangat memperhatikan Kode Etik Jurnalistik, dimana Pasal 2 Kode Etik Jurnalistik menyebutkan "Wartawan Indonesia menempuh cara-cara yang profesional dalam melaksanakan tugas jurnalistik". Cara profesional itu antara lain "tidak melakukan plagiat, termasuk menyatakan hasil liputan wartawan lain sebagai karya sendiri, "wartawan adalah seseorang yang menjalankan profesi jurnalistik. Redaksi Tempo dalam konnstruksi editorialnya yang berjudul "Penembakan oleh Polisi di era Orde Baru" merekonstruksi pengambilan dan pemuatan sudah dilengkapi dengan keterangan tentang sumber dan ditampilkan secara berimbang dan menghormati pengalaman traumatik narasumber. Majalah Tempo menyampaikan dokumentasi hasil liputan wartawan lain sebagai karya sendiri.

11. Struktur mikro redaksi Tempo dalam narasinya juga melakukan metafora dengan menggunakan frasa "korban-korban petugas ngoboi" Gaya bahasa metafora ini banyak digunakan diberbagai karya sastra yang mana tujuannya untuk mengungkapkan suatu makna dengan penekanan pada kesan yang akan ditimbulkan. Dengan itu, penggunaan juga ditujukan agar mengatasi suatu keterbatasan pilihan kata atau juga suatu bentuk ekspresi seorang penulis. Dengan menggunakan kata-kata atau frasa yang memiliki makna kiasan untuk menyamakan atau membandingkan suatu objek dengan objek lainnya. Selebihnya tidak digunakan kata penghubung atau konjungsi pada kalimat-kalimatnya

\section{B. Hasil Analisa: Editorial: Pentingnya Mengungkap Pembunuhan Ekstrayudisial Laskar Front Pembela Islam}

1. Masih di ranah editorial majalah Tempo, kali menyoal pandangan redaksi soal pentingnya mengungkap pembunuhan ekstrayudisial laskar Front Pembela Islam. Secara makro narasi yang dibangun adalah sinyalemen presiden Joko Widodo membentuk tim pencari fakta independen dan menyerahkan penyelidikan kasus ini kepada Badan Reserse Kriminal Kepolisian Republik Indonesia. Namun redaksi Tempo menyadari secara struktur skematik, sangat sulit berharap polisi bisa bersikap obyektif ketika memeriksa sesamanya.

2. Strategi wacana jurnalisme investigasi yang terdapat pada subtema ini yaitu kegiatan meminta kepada pemerintah mengusut tuntas dugaan pembunuhan ekstrayudisial dalam kasus ini. Polisi adalah aparat penegak hukum, bukan koboi yang bisa beraksi di atas hukum. Supremasi hukum atau rule of law adalah prinsip utama dalam negara demokrasi. Semua orang, termasuk polisi, harus sama kedudukannya di depan hukum.

3. Redaksi Tempo dalam editorialnya secara detail mendiskripsikan terkait dugaan ada pelanggaran hukum dalam kasus penembakan laskar FPI ini cukup beralasan. Sejauh ini, penjelasan dan bukti yang disodorkan Kepala Kepolisian Daerah Metropolitan Jakarta Raya Inspektur Jenderal Fadil Imran banyak bolong di sana-sini. Pertama, dalih Fadil bahwa penembakan para pengawal pentolan FPI, Rizieq Syihab, ini dilakukan sebagai upaya membela diri tak didukung cukup bukti. Entah kebetulan entah tidak, kamera pengawas (CCTV) di lokasi kejadian, yakni dekat kilometer 50 jalan tol Jakarta-Cikampek, temyata rusak. Akibatnya, klaim bahwa laskar FPI menembak lebih dulu dengan dua pucuk pistol revolver kaliber 9 milimeter sulit diverifikasi. Apalagi asal muasal pistol ini pun tampak meragukan. Kedua, foto-foto jenazah korban menunjukkan peluru menyasar titik-titik mematikan di tubuh manusia. Pada keenam jenazah anggota laskar FPI ada lubang bekas tembakan di dada sebelah kiri, dekat jantung. Baku tembak dari mobil yang melaju kencang sulit menghasilkan Iuka tembak yang demikian presisi dan seragam.

4. Padahal dalam penulisan struktruk mikro redaksi majalahTempo memiliki anggapan, bahwa pemerintah memiliki kewajiban mengusut tuntas dugaan pembunuhan ekstrayudisial. Bahkan dalam narasnya disebutkan polisi adalah aparat penegak hukum, bukan koboi yang bisa beraksi di atas hukum. Jika benar terjadi, aksi main hakim sendiri semacam ini tak boleh dibiarkan. Kali ini korbannya kelompok seperti FPI, tapi siapa yang menjamin aksi serupa tak dilakukan polisi kepada warga negara lain di kemudian hari?

5. Tujuan penulisan editorial majalah Tempo dengan tegas mengatakan Supremasi hukum atau rule of law adalah prinsip utama dalam negara demokrasi. Semua orang, termasuk polisi, harus sama kedudukannya di depan hukum. Kepala Polri Jenderal Idham Azis harus bersedia bekerja sama dengan tim pencari fakta independen atau lembaga negara seperti Komisi Nasional Hak Asasi Manusia, yang tengah mengusut kasus ini.

6. Dalam narasinya editorial Tempo memiiliki anggapan, dalam situasi seperti ini, Presiden Joko Widodo seharusnya memberikan instruksi politik yang jemih dan jelas bahwa penegakan hukum harus menjadi panglima. Ruang interpretasi yang keliru atas situasi yang panas harus ditutup rapat-rapat. Jika tidak, para aparat di lapangan bisa menafsirkan sendiri-sendiri kemauan politik penguasa. Dengan kata lain pemerintah mengusut tuntas dugaan 
pembunuhan ekstrayudisial dalam kasus ini. Karena masalah ini berhubungan dengan supremasi hukum atau rule of law adalah prinsip utama dalam negara demokrasi. Semua orang, termasuk polisi, harus sama kedudukannya di depan hukum

7. Tempo meminta Kepala Polri Jenderal Idham Azis harus bersedia bekerja sama dengan tim pencari fakta independen atau lembaga negara seperti Komisi Nasional Hak Asasi Manusia, yang tengah mengusut kasus ini. Dukungan sebagian kalangan terhadap aksi penembakan laskar FPI ini sungguh tidak pada tempatnya. Menyebut aksi-aksi intoleran FPI sebagai dalih pembenar untuk dugaan pembunuhan ini juga sesat pikir. Berbagai pelanggaran yang dilakukan FPI tentu harus dihadapi dengan penegakan hukum yang tegas, bukan aksi balas dendam yang justru melanggar hukum itu sendiri. Dalam subtema ini pula dipaparkan pernyataan Siaran pers Poldan Metro dan keterangan juru bicara FPI Munarman .

8. Selebihnya redaksi Tempo dalam struktur mikro menggunakan metofora dengan frasa "pembunuhan ekstrayudisial" yaitu mengungkapkan suatu makna dengan penekanan pada kesan yang akan ditimbulkan sekaligus membandingkan suatu objek atau keadaan dengan memakai perbandingkan langsung tanpa adanya kata pembanding seperti kata bagaikan, laksana, atau bak.

9. Dalam narasi yang dikonstruksi editorial majalah Tempo cukup berhati-hati dalam penulisannya, hampir semua fakta yang disajikan memiliki sumber yang dapat dipertanggungjawabkan, sehingga kekeliruan informarsi dapat diminimalisir untuk menghdari hak jawab atau somasi dari pihak-pihak yang merasa dirugikan.

\section{Hasil Analisis Judul : Nasib Enam Anggota FPI, Diringkus Hidup-hidup, Berakhir di Kamar Mayat}

1. Dalam jurnalistik investigasi akurasi kronologi dalam kasus yang saling bersitegang antara Polisi dan FPI, majalah Tempo terlihat sangat "berhati-hati" untuk memenuhui unsur cover both side. Dari struktur makro wartawan Tempo berusaha meperlihatkan foto-foto jenazah enam anggota Laskar Khusus FPI itu pada Kamis, 10 Desember lalu. Terdapat jenazah yang memiliki dua, tiga, atau empat lubang, dengan noda hitam di sekelilingnya. Total ada 19 bekas timah panas di tubuh mereka. Tempo juga mewancarai paman korban yang ikut memandikan jenasah. Selebihnya Tempo juga mendapat keterangan dari ahli forensic.

2. Wartawan Tempo menemukan kesamaan: sebagian besar lubang itu ada di dada kiri.
Jenazah mereka dikuburkan pada Jumat, 11 Desember lalu. Secara struktur makro narasi yang dikembangkan majalah Tempo adalah deskripsi kondisi jenasah lascar FPI di sebuah kamar mayat.

3. Bahkan lebih detail Tempo mendiskripsikan dengan baik dengan diskripsi situasioal. : Edwin-nama samaran-mendengar suara dua benda keras beradu dari ujung telepon. Selama sekitar 8 menit, dia berkomunikasi dengan Ahmad Sofiyan alias Ambon melalui telepon WhatsApp. Dua anggota Front Pembela Islam itu menumpang mobil berbeda. Edwin menumpang Toyota Avanza, sementara Ahtnad menaiki Chevrolet Spin. Menurut Edwin, terdapat enam orang di tiap kendaraan. Mobil Edwin dan Ahmad masuk rombongan Rizieq Syihab yang berangkat dari perumahan The Nature Mutiara Sentul pada Ahad tengah malam, 6 Desember lalu. Konvoi itu terdiri atas delapan mobil, empat di antaranya diisi keluarga Rizieq. Menurut Edwin, setidaknya ada empat mobil yang membuntuti mereka. Mengetahui ada mobil pengintai, enam mobil memisahkan diri sejak keluar dari pintu tol Karawang Timur. Adapun mobil Edwin dan Ahmad berbelok ke Jalan Klari di dalam Kota Karawang.

4. Di sana, mereka kejar-kejaran dengan mobil polisi. Menurut Edwin, mereka saling pepet dan potong jalur. Selama itu, panggilan telepon Edwin dengan Ahmad tak pemah putus. Sebelumnya, mereka berkomunikasi lewat pesan suara aplikasi grup WhatsApp bemama "Ikan Rias Cupang Giant". Setelah melewati tiga persimpangan lampu lalu lintas, mobil Edwin lolos dan masuk ke gerbang tol Karawang Barat. Melaju sekitar tiga kilometer dari pintu tol, dia menunggu Ahmad yang tercecer di belakang. Suara mobil bertabrakan itulah yang terakhir terdengar di telepon. "Mobilnya tak pemah muncul, lalu suara di telepon senyap dan putus," tutur Edwin. Mobil Edwin kemudian melaju, lalu berhenti di Rest Area Kilometer 57. Seorang narasumber yang menelusuri tewasnya anggota FPI ini mengatakan sempat terjadi tembak-menembak antara tim polisi dan pengawal Rizieq di mobil Chevrolet Spin. Baku tembak itu terjadi sebelum mobil masuk ke jalan tol. Petunjuk penting dari kontak senjata itu ditemukan di dekat bundaran Jalan International Karawang Barat. Tempo memperoleh tiga foto di lokasi itu yang menggambarkan penemuan proyektil dan selongsong peluru yang tercecer di sekitar rerumputan di pinggir jalan menuju gerbang tol Karawang Barat.

5. Sementara redaksi Tempo dalam laporan kronologinya juga ingin melindungi sumber dengan menyebutkan nama samaran." Edwin"Hal ini sesuai dengan pasal 7 Kode Etik 
Jurnalistik dimana; Wartawan Indonesia memiliki hak tolak untuk melindungi narasumber yang tidak bersedia diketahui identitas maupun keberadaannya, menghargai ketentuan embargo, informasi latar belakang, dan off the record sesuai dengan kesepakatan.

6. Hal ini dimaksudkan dalam UU No. 40 Tahun 1999 tentang Pers ("UU Pers") tidak mengenal istilah "objek berita" atau "subjek berita". Namun, di dalam Pasal 1 angka 10 UU Pers yang menjelaskan definisi hak tolak terdapat istilah "sumber berita". Bunyi selengkapnya Pasal 1 angka 10 UU Pers adalah sebagai berikut: "Hak Tolak adalah hak wartawan karena profesinya, untuk menolak mengungkapkan nama dan atau identitas lainnya dari sumber berita yang harus dirahasiakannya."

7. Sementara standart dalam jurnalistik investigasi adalah " koherensi" seperti yang diungkapkan sebuah artikulasi elemen ke-5 jurnalisme: untuk memantau kekuasaan (Bill Kovach-Tom Rosenstiel, 2001). Menurut Leonard Seller adalah upaya menyingkap informasi yang sengaja ditutupi karena pelanggaran etika dan hukum. Hal yang hampir serupa disampaikan Brit Hume, yaitu sebuah laporan kepada publik atas informasi yang oleh pemerintah dilarang keras untuk diketahui.

8. Dengan tujuan agar kewajiban pemerintah mengusut tuntas dugaan pembunuhan ekstrayudisial dalam kasus ini Hal ini berhubungan dengan supremasi hukum atau rule of law adalah prinsip utama dalam negara demokrasi. Semua orang, termasuk polisi, harus sama kedudukannya di depan hukum.

9. Secara umum dalam kaitanya diatas redaksi Tempo ingin 1) Mengungkap kejahatan terhadap kepentingan atau yang merugikan masyarakat sipil tidak bersenjata 2) Skala kasus cenderung terjadi secara luas atau sistematis. 3) Menjawab semua pertanyaan penting danmemetakan persoalan dengan gambling 4) Mendudukkan aktor-aktor yang terlibat secara lugas, didukung bukti-bukti kuat 5)Publik bisa memahami kompleksitas masalah yang dilaporkan dan bisa membuat perubahan.

10. Redaksi Tempo memeiliki anggapan, dalam situasi seperti ini, Presiden Joko Widodo seharusnya memberikan instruksi politik yang jemih dan jelas bahwa penegakan hukum harus menjadi panglima. Ruang interpretasi yang keliru atas situasi yang panas harus ditutup rapat-rapat. Jika tidak, para penggawa di lapangan bisa menafsirkan sendiri-sendiri kemauan politik penguasa.

11. Bahkan redaksi Tempo menggunakan kata ganti " mereka" Tempo ingin menggambarkan bahwa memberangus mereka dengan aksi ekstrayudisial seperti yang terjadi selama Orde Baru terbukti tak menyelesaikan masalah.

\section{Hasil Analisis Judul : "Dari Enam Tersangka, Hanya Rizieq yang Masuk Penjara}

Berangkat dari sejumlah hal prinsip yang membedakan jurnalisme investigatif dari laporan jurnalistik yang 'biasa' atau konvensional (conventional news reporting). Liputan berita biasa sebagian besar bergantung pada bahan yang disampaikan oleh pihak lain seperti polisi, pemerintah, perusahaan-perusahaan; seringkali bersifat pasif atau reaktif. Sedangkan liputan investigatif lebih mengandalkan bahan-bahan yang dikumpulkan dan dibangun melalui inisiatif reporter sendiri. Liputan berita konvensional bertujuan menciptakan gambaran objektif dunia atau keadaan seperti apa adanya (to create an objective image of the world as it is). Sedangkan liputan investigatif lebih dari itu yakni memanfaatkan gambaran objektif tentang suatu fakta atau peristiwa untuk mewujudkan tujuan mengubah dan memperbaiki keadaan.

1. Menyoal judul diatas yang dikaitan dengan kegiatan jurnalisme investigasi, redaksi Tempo terlihat mendesak institus Polri lebih transparan soal terminology "pelanggaran" dan "menghasut". Apalagi unsur mengahsut tidak menimbulkan akibat.

2. Narasi pemberitaan yang dibangun majalah Tempo dengan tema Polda Metro Jaya memutuskan menahan pentolan Front Pembela Islam. Dengan skema alur narasi. Selama pemeriksaan, penyidik mengajukan 84 pertanyaan. Salah satu alasan polisi menahan Rizieq adalah ancaman hukumannya lebih dari lima tahun penjara."

3. Secara sematik narasi yang dibangun Tempo dengan latar belakang alasan Polisi menjerat Rizieq dengan Pasal 160 Kitab UndangUndang Hukum Pidana tentang penghasutan dengan ancaman maksimal enam tahun penjara dan Pasal 216 KUHP tentang menolak mengikuti peraturan yang sedang berlaku dengan ancaman hukuman empat bulan dua minggu penjara.

4. Untuk memperkuat sinyalemen diatas majalah Tempo menampilkan secara detai kronologi hasil gelar perkara: Menurut polisi, tindakan Rizieq memenuhi unsur penghasutan dan mengajak orang lain untuk membangkang dari ketentuan hukum serta menghambat tugas aparat negara terkait dengan penanggulangan pandemi Covid19. "Karena takut, dia menyerah dan datang sendiri," kata Kepala Bidang Hubungan Masyarakat Polda Metro Jaya Komisaris Besar Yusri Yunus. Selanjutnya Yusri menjelaskan, penetapan status tersangka dibuat setelah tim penyidik SubDirektorat Keamanan Negara 
memaparkan hasil pemeriksaan dalam satu forum gelar perkara, Selasa, 8 Desember lalu. Mereka mengandalkan keterangan sejumlah saksi yang mengetahui kronologi acara pernikahan dan maulid itu. Polisi mengambil kesaksian dari panitia penyelenggara acara pemikahan sebanyak enam orang. Dimana kesimpulannya unsur perbuatan pidana keenam tersangka sudah terpenuhi.

5. Secara tujuan dalam narasinya majalah Tempo ingin: membedah alur cerita Polda Metro Jaya karena menetapkan Imam Besar Front Pembela Islam (FPI) Habib Rizieq Shihab (HRS) sebagai tersangka kasus kerumunan pernikahan anaknya. Sebagai dugaan awal, redaksi Tempo beranggapan kasus tersebut bukan sebuah kejahatan dengan pemberatan seperti perampokan dan sebagainya.

6. Dalam hal ini redaksi tempo mempersoalkan tindakan polisi yang menjerat HRS dengan pasal 160 KUHP. Benarkah pasal 93 UU Kekarantinaan Kesehatan dianggap kurang untuk dapat dijadikan alat melegitimasi untuk menangkap dan menahan HRS. Redaksi Tempo juga ingin mempertanyakan dimana unsur menghasut yang disangkakan

7. Secara tehnis investigasi Tempo mencoba melakukan kritik terhadap Polda Metro Jaya karena menetapkan Imam Besar Front Pembela Islam (FPI) Habib Rizieq Shihab (HRS) sebagai tersangka kasus kerumunan pernikahan anaknya pada Sabtu lalu (14/11). Padahal hal yang paling fundamental tentang tujuan hukum. Salah satunya adalah ketertiban masyarakat Disisni redaksi Tempo melihat bahwa tindakan HRS menimbulkan kerumunan di masa pandemi virus corona baru (Covid-19) merupakan sebuah kesalahan. Meski demikianTempo menganggap tindakan itu bukan sebuah kejahatan dengan pemberatan seperti perampokan dan sebagainya.Tempo juga mempersoalkan tindakan polisi yang menjerat HRS dengan pasal 160 KUHP. Sebabnya, pasal 93 UU Kekarantinaan Kesehatan dianggap greget , untuk dapat dijadikan alat melegitimasi untuk menangkap dan menahan HRS. Tempo juga mempertanyakan dimana unsur menghasut yang disangkakan kepada HRS, dalam kasus kerumunan yang menjeratnya?

8. Majalah Tempo beranggapan dalam situasi seperti ini, KAPOLRI seharsus lebih transparan soal unsur "menghasut". Redaksi Tempo mempertanyakan darimana muncul akibatnya? Apalagi ketika akibat yang dikhawatirkan itu tidak terjadi.

9. Disisi lain pihak FPI yang diwakili Munarman mengakui bahwa Rizieq Syihab melakukan pelanggaran protokol kesehatan karena acara itu memantik kerumunan. Sanksi atas pelanggaran tersebut sudah dijalankan kliennya dengan membayar denda sebesar Rp 50 juta. Ia menganggap Rizieq tak bisa dihukum atas tuduhan yang sama. Dirinya beranggapan setiap warga negara tidak boleh dihukum dua kali atas pelanggaran yang sama sebagai prinsip nebis in idem.

10. Dalam struktur mikro stilistik penggunaan frasa "penjara" adalah makna yang bersifat tetap dan tidak terikat dengan kata lainnya (berdiri sendiri).

11. Secara retoris dalam elemen metafora terdapat penggunaan frasa "Pentingnya mengungkap pelanggaran dan kejahatan"

12. Secara umum redaksi Tempo sudah sangat memperhatikan fungsi pers menurut UU 40 tahun 1999 tentang Pers adalah wahana komunikasi massa, penyebar informasi, dan pembentuk opini harus dapat melaksanakan asas, fungsi, hak, kewajiban, dan peranannya dengan sebaikbaiknya berdasarkan kemerdekaan pers yang profesional, sehingga harus mendapat jaminan dan perlindungan hukum, serta bebas dari campur tangan dan paksaan dari manapun. Pers nasional juga memiliki peran menjaga ketertiban dunia yang berdasarkan kemerdekaan, perdamaian abadi dan keadilan sosial.

13. Dengan kata lain redaksi Tempo melakukan liputan investigatif yakni berusaha memanfaatkan gambaran objektif tentang suatu fakta atau peristiwa untuk mewujudkan tujuan mengubah dan memperbaiki keadaan

\section{E. Hasil Analisis Judul : "Istirahat Panjang Rizieq Syihab di Megamendung"}

Berangkat dari sejarah tulisan investigasi Ida Tarbel yang kemudian dibukukan dengan judul History of Standart Oil Company dan menjadi catatan laporan investigai yang legendaris. Tarbel merekonstruksi laporan dengan gaya Mucraking (pembedahan) sangat mendapat tempat dalam jurnalistik di Amerika. Latar belakang menjadikan Tempo sebgai catatan khusus soal sejarah yang akan ikut membedah masalah pokok

1. Disisi lain redaksi Tempo merekonstruksi secara sistematis berkenaan dengan problematik untuk dicermati. Harapan redaksi Tempo menyesuaikan harapan dan realitas yang ingin pembaca ketahui. Tidak semua masalah itu dianggap menarik oleh publik, namun redaksi Tempo memncoba membedah sisi lain yang banyak mendapat perhatian publik, salah satunya pesantren milik Habib Risziq di Megamendung. Inside ini dimaksudkan untuk menjelaskan alasan mengapa HRS berada di Megamendung, dan apa yang dikerjakan disana.

2. Diawali dengan cerita latar mengenai keamanan untuk ke pondok milik Rizieq itu. Karena banyak orang tak dikenal berseliweran di sekitar pondok, Laskar FPI membentengi kawasan pesantren. Ada tiga pos yang harus dilewati untuk sampai ke 
pondok. Di pos pertama yang dilengkapi portal, Laskar FPI mengecek semua kendaraan.

3. Bahkan majalah Tempo secara detail digambarkan kegiatan Habib Rizieq di pondok itu berbeda dibandingkan dengan setelah dia kembali dari Arab Saudi pada Selasa, 10 November lalu. Di rumahnya di Petamburan, Jakarta Pusat, dia menerima banyak tamu. Rizieq pun menggelar acara Maulid Nabi dan pemikahan anaknya yang dihadiri ribuan orang. Tak lama seusai berbagai kegiatan itu, Rizieq jatuh sakit dan dirawat di Rumah Sakit Ummi, Bogor. Dua hari dirawat, Rizieq diam-diam meninggalkan rumah sakit pada 28 November lalu lewat pintu belakang.

4. Dia pun disebut-sebut positif Covid-19. Tapi Sobri Lubis membantah dan mengatakan bahwa Rizieq hanya mengalami kelelahan. Setelah keluar dari rumah sakit, Rizieq mengaku banyak menghabiskan waktu di pondoknya itu. Dia memilih menetap di sana karena udaranya sejuk. "Udara asri dan segar jadi untuk pemulihan luar biasa sekali," ucap Rizieq dalam video yang diunggah di akun YouTube Front Pembela Islam, Front TV, pada Jumat malam, 11 Desember lalu. Sobri Lubis pun mengatakan Rizieq tak mengalami batuk dan flu.

5. Tak hanya berdiam di Megamendung, Habib Rizieq mengaku sesekali berkunjung ke rumahnya di Petamburan dan Sentul, Jawa Barat, untuk menengok anak dan cucunya. Menurut Sobri Lubis, Rizieq sempat terguncang setelah mendengar enam pengawalnya tewas ditembak oleh polisi pada Senin dinihari, 7 Desember lalu. "Beliau dan keluarganya menangis," kata Sobri. Di sela-sela kegiatan Rizieq, Kepolisian Daerah Metropolitan Jakarta Raya pada 1 dan 7 Desember lalu memanggilnya terkait dengan kasus kerumunan di Petamburan. Rizieq yang tak hadir membantah anggapan kabur dari pemeriksaan tersebut. Dia menyatakan kondisinya belum stabil sehingga tak bisa hadir. Rizieq pun mengutus tim pengacara untuk meminta polisi menunda pemeriksaan. Pada Kamis, 10 Desember lalu, polisi menetapkan Rizieq sebagai tersangka kasus kerumunan.

Dari sisi bangunan narasi yang dikembangkan redaksi Tempo memiliki tujuan memberikan diskripsi situasional mencoba memaparkan, menguraikan atau melukiskan. Dalam paragraf mendeskripsikan Imam besar Front Pembela Islam itu menghabiskan waktunya untuk beristirahat. Ketua Umum Front Pembela Islam Ahmad Sobri Lubis bercerita, Rizieq berupaya memulihkan kondisi kesehatannya.

\section{KESIMPULAN}

Pokok pemikiran analisis Van Dijk adalah, bagaiman peristiwa tersebut dimengerti, dimaknai dan ditampilkan dalam pikiran si wartawaan, karena melalui proses pemaknaan wartawan membantu memahami fenomena sebagai bagian dari proses produksi berita.

Dua strategi Jurnalisme investigasi dalam editorial Tempo, Pertama mengingatkan masyarakat pembaca dengan mengkomperasi sebuah fakta hasil investigasi saat Orde Baru berkuasa, dimana aparat keamanan seolah-olah "dihalalkan" menembak orang yang masih "patut diduga" melakukan tidakan yang dianggap kriminal. Kedua, dengan tegas mengatakan supremasi hukum atau rule of law adalah prinsip utama dalam negara demokrasi. Semua orang, termasuk polisi, harus sama kedudukannya di depan hukum.

Selanjutnya majalah Tempo ingin memperlihatkan akurasinya adalam menyususn kronologi penembakan Anggota FPI. Tempo terlihat sangat "berhati-hati" untuk memenuhui unsur cover both side. Seperti dalam laporannya yang berjudul; "Nasib Enam Anggota FPI, Diringkus Hidup-hidup, Berakhir di Kamar Mayat. Dalam liputannya keterangan dari FPI dan Polisi ditampilkan secara seimbang.

Demi mnenaati pasal 7 Kode Etik Jurnalistik wartawan Tempo memiliki sangat melindungi narasumber yang tidak bersedia diketahui identitas maupun keberadaannya. Seperti menyebutkan nama samara anggota FPI dengan menggunakan nama Erwin,

Seecara sematik majalah Tempo membangun narasi dengan latar belakang alasan mengapa Polisi menjerat Rizieq dengan Pasal 160 Kitab Undang Undang Hukum Pidana tentang penghasutan dengan ancaman maksimal enam tahun penjara dan Pasal 216 KUHP tentang menolak mengikuti peraturan yang sedang berlaku dengan ancaman hukuman empat bulan dua minggu penjara

Sebagai penutup melalui diskripsi situasional majalah Tempo memaparkan, menguraikan atau melukiskan HRS berkegiatan Megamendung soal upaya memulihkan kondisi kesehatan sebelum ditahan oleh Polda Metro Jaya. Laporan ini dirapkan dapat memberikan kesan atau impresi kepada para pembaca terhadap objek, peristiwa, gagasan, secara otentik.

\section{REFERENSI}

Asprilla, A., \& Maharani, N. (2019). Jurnalisme Data Dalam Digitalisasi Jurnalisme Investigasi Tempo. Jurnal Kajian Jurnalisme, 3(1), 212224. https://doi.org/10.24198/kj.v3i1.21362

$\mathrm{K}$, septiawan santana. (2009). jurnalisme investigasi. jakarta: yayasan obor indonesia.

laksono, dwi D. (2010). Jurnalisme Investigasi (1st 
ed.). bandung: Kaifa.

Letezia Tobing, S.H., M. K. (n.d.). Mekanisme Penyelesaian atas Pemberitaan Pers yang Merugikan. Retrieved from hukum online.com website:

https://www.hukumonline.com/klinik/detail/ul asan/lt509886c80973d/tanggung-jawab-

keperdataan-media-cetak-dalam-memuatberita-yang-salah/

Letezia Tobing, S.H., M. K. (2013). Tentang Asas Praduga Tak Bersalah. Retrieved from https://www.hukumonline.com/klinik/detail/ul asan/cl2663/tentang-asas-praduga-takbersalah/

Ms, amir machmud. (n.d.). mengartikulasi trial by the pree dalam kemasan pemberitaan media yang berorientasi kemaslahatan. 0, 1-8. Retrieved from https://www.neliti.com/id/publications/179303 /mengartikulasikan-trial-by-the-press-dalamkemasan-pemberitaan-media-yang-berori

Sobur, A. (2012). analisis teks media: suatu pengantar analisa wacana, analisis semiotika dan analisis framing. Remaja Rosda karya.

Wina, S. A. (2012). Kajian Tuntas 350 Tanya Jawab.

\section{PROFIL PENULIS}

Arvin Hardian, lahir di Madiun 1966. Menempuh Pendidikan S1 bidang Komunikasi dan S2 manajemen bidang komunikasi bisnis, saat ini sedang menyelesaikan jenjang S2 di Pascasarjana Usahid mengambil komunikasi. Aktif bekerja sebagai wartawan, public relations di Net Communication, dan direktur dibeberapa perusahaan. Selain sebagai praktisi komunikasi juga mengajar sebagai dosen di Interstudi, UBSI, UPN, dan Nusa Mandiri

Tuty Mutiah, Menamatkan program strata satu di Universitas BSI Bandung jurusan komunikasi. Dan program strata dua di Universitas BSI Bandung jurusan Manajemen dan saat ini sedang menyelesaikan jenjang S2 di Pascasarjana Usahid mengambil komunikasi. Saat ini freelancer di production house sebagai penulis naskah, casting director dan talent cooedinator. Sedangkan untuk iklan sebagai Manager Unit Dan saat ini juga mengajar sebagai dosen di Universitas Bina Sarana Informatika Fakultas Komunikasi dan Bahasa Program Studi penyiaran dengan mengajar di prodi penyiaran.

Wulan Apriani lahir di Jakarta 1986. Menempuh Pendidikan S1 dibidang Manajemen Komunikasi di Universitas Padjajaran Bandung, dan sedang menempuh S2 di Pascasarjana Usahid mengambil kajian Komunikasi Politik. pernah menjadi tenaga pengajar dan Staf akademik di BSI pada tahun 2008 - 2011, menjadi tenaga pengajar dan sekertaris Prodi Komunikasi di Univ Mummadiyah Tangerang 2012 -2018 .

Agung Raharjo, Menamatkan program strata satu di Universitas BSI Bandung jurusan komunikasi. Dan program strata dua di Universitas BSI Bandung jurusan Manajemen dan saat ini sedang menyelesaikan jenjang S2 di Pascasarjana Usahid mengambil komunikasi. Saat ini bekerja di MNC TV sebagai penata kamera dan juga menjadi salah satu pengajar di Universitas BSI Fakultas Komunikasi dan Bahasa Jurusan penyiaran dengan mengajar mata kuliah dokumenter. 